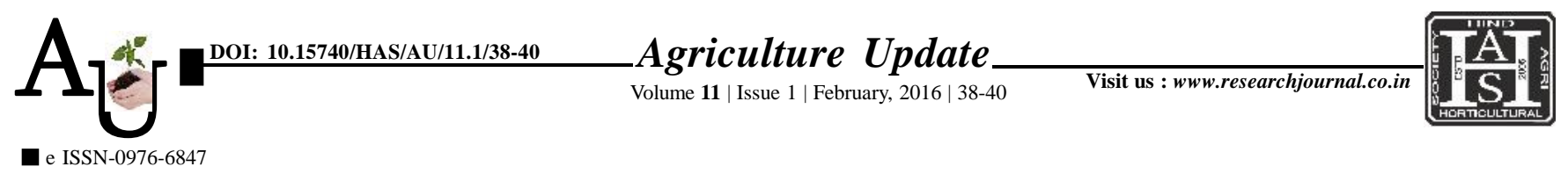

\title{
Research Article: Impact of Stree Shakthi Programme on beneficiaries income generation and its utilization pattern
}

\author{
N.P. DHANANJAYA, M.P. GOKULRAJ, V.L. MADHU PRASAD AND \\ K. VENKATARANGA NAIKA
}

Article Chronicle: Received :

21.08.2014;

Revised :

30.12.2015;

Accepted :

14.01.2016

KeY Words:

Impact, Income generation, Income utilization, Beneficiaries

Author for correspondence :

\section{V.L. MADHU PRASAD}

Directorate of

Agricultural Extension,

University of

Agricultural Sciences,

Hebbal, BANGALURU

(KARNATAKA) INDIA

Email: madhuprasad.

extn@gmail.com

See end of the article for

authors' affiliations
SUMMARY : Present study was conducted purposively in selected Chitradurgra and Hiriyur talukas of Chitradurgra district based on maximum number of Stree Shakthi Groups (SSGs).Twelve SSGs from each taluka and five members from each group were selected thus making a total of 120 . The results indicated that majority of SSP beneficiaries' generated income from dairy $(91.67 \%)$ followed by agriculture $(83.34 \%)$ and NREGA works (50\%). It was also observed that 83.33 per cent of beneficiaries utilized their income towards purchase of sheep/goat followed by milch animal (75\%), house articles $(72.50 \%)$, festivals $(69.16 \%)$, health checkup $(64.17 \%)$, cattle feed $(62.50 \%)$, loan repayment $(62.50 \%)$, children education $(60.00 \%)$, groceries $(58.43 \%)$ and cattle vaccination. Hence, poverty in the rural areas could be eradicated by empowering women through programmes like SSP.

How to cite this article : Dhananjaya, N.P., Gokulraj, M.P., Prasad, V.L. Madhu and Naika, K.Venkataranga (2016). Impact of Stree Shakthi Programme on beneficiaries income generation and its utilization pattern. Agric. Update, 11(1): 38-40. 